\title{
Anisotropic Shape-Memory Alginate Scaffolds Functionalized with either Type I or Type II Collagen for Cartilage Tissue Engineering
}

\author{
Henrique V. Almeida, ${ }^{1,2}$, Binulal N. Sathy ${ }^{1,2}$, Ivan Dudurych ${ }^{1,3}$, Conor T. Buckley ${ }^{1,2}$, \\ Fergal J. O’Brien ${ }^{1,4,5}$, Daniel J. Kelly ${ }^{1,2,4,5 *}$
}

1 Trinity Centre for Bioengineering, Trinity Biomedical Sciences Institute, Trinity College Dublin, Dublin 2, Ireland

${ }^{2}$ Department of Mechanical and Manufacturing Engineering, School of Engineering, Trinity College Dublin, Dublin 2, Ireland

${ }^{3}$ School of Medicine, Trinity Biomedical Sciences Institute, Trinity College Dublin, Dublin 2, Ireland

${ }^{4}$ Advanced Materials and Bioengineering Research Centre (AMBER), Trinity College Dublin \& Royal College of Surgeons in Ireland, Dublin 2, Ireland

5 Tissue Engineering Research Group, Department of Anatomy, Royal College of Surgeons in Ireland, Dublin 2, Ireland

${ }^{*}$ Corresponding author: Daniel J. Kelly, Ph.D.

Address: Department of Mechanical and Manufacturing Engineering, School of Engineering, Parson's Building Trinity College Dublin, Dublin 2, Ireland

Telephone: +353-1-896-3947, Fax: +353-1-679-5554

E-mail address: kellyd9@tcd.ie 


\section{Abstract}

Regenerating articular cartilage and fibrocartilaginous tissue such as the meniscus is still a challenge in orthopedic medicine. While a range of different scaffolds have been developed for joint repair, none have facilitated the development of a tissue that mimics the complexity of soft tissues such as articular cartilage. Furthermore, many of these scaffolds are not designed to function in mechanically challenging joint environments. The overall goal of this study was to develop a porous, biomimetic, shape-memory alginate scaffold for directing cartilage regeneration. To this end, a scaffold was designed with architectural cues to guide cellular and neo-tissue alignment, which was additionally functionalized with a range of extracellular matrix (ECM) cues to direct stem cell differentiation towards the chondrogenic lineage. Shape-memory properties were introduced by covalent crosslinking alginate using carbodiimide chemistry, while the architecture of the scaffold was modified using a directional freezing technique. Introducing such an aligned pore structure was found to improve the mechanical properties of the scaffold, and promoted higher levels of sGAG and collagen deposition compared to an isotropic (non-aligned) pore geometry when seeded with adult human stem cells. Functionalization with collagen improved stem cell recruitment into the scaffold and facilitated more homogenous cartilage tissue deposition throughout the construct. Incorporating type II collagen into the scaffolds led to greater cell proliferation, higher sGAG and collagen accumulation, and the development of a stiffer tissue compared to scaffolds functionalized with type I collagen. The results of this study demonstrate how both scaffold architecture and composition can be tailored in a shape-memory alginate scaffold to direct stem cell differentiation and support the development of complex cartilaginous tissues.

Keywords: Cartilage, Extracellular Matrix, Biomimetic Materials, Polymeric Scaffolds, Meniscus. 


\section{Introduction}

Articular cartilage it is a highly specialized anisotropic tissue that functions to support joint contact forces and to reduce friction within the joint $(1,2)$. Regenerating this complex tissue is still a challenge in the field of orthopedic medicine, due in part to its avascular nature $(3,4)$. Chondral and osteochondral lesions often result in pain and swelling, followed by further joint degeneration and eventually osteoarthritis $(3,4)$. Injuries to cartilage can be treated with a range of approaches, including marrow stimulation techniques (5), mosaicplasty $(6)$ and cell-based therapies $(3,7)$ such as autologous chondrocyte implantation (ACI) (8), matrix-induced autologous chondrocyte implantation (MACl) (9) or the use of adult stem cells (10). Similar challenges exist when trying to regenerate other joint tissues such as the meniscus (11). In the context of both articular cartilage and meniscus regeneration, novel scaffolds are required that are not only mechanically robust and compatible with the load bearing environment of a synovial joint, but which can also direct progenitor cells down the chondrogenic or fibro-chondrogenic pathway and promote the development of an organized tissue.

Porous scaffolds for cartilage tissue engineering can be fabricated using different rawmaterials and manufacturing techniques $(10,12,13,14)$. Ideally these biomaterials should be instructive to cells that are seeded or recruited into the scaffold $(10,15)$. Native extracellular matrix (ECM) $(16,17)$ and it derivatives such as collagen $(18,19)$ and hyaluronic acid $(20)$, as well as other natural polymers such as chitosan $(21,22)$ and alginate $(23-26)$, are commonly used as biomaterials in cartilage tissue engineering. Furthermore, inert biomaterials can be functionalized to promote chondrogenesis through the incorporation of cartilage specific ECM components such as type II collagen $(21,22,27-29)$. Alginate is a relatively inert polysaccharide that is commonly used as a biomaterial in the field of tissue engineering $(10,25)$. Highly porous shape-memory scaffolds can be produced by covalently crosslinking alginate using carbodiimide chemistry (23, $24,30)$. Such scaffolds can be compressed to a fraction of their original height and then return to their initial shape when rehydrated (30). A potential limitation with these scaffolds is poor cellular infiltration and attachment, although this can be improved through the incorporation of different 
ECM components, such as fibronectin (31) or collagen (24). The unique mechanical properties of these shape-memory alginate scaffolds make them highly attractive for implantation into load bearing environments such as synovial joints, however their structure and composition must firstly be optimized for promoting chondrogenesis and the development of an organized tissue.

It is known that tissue architecture plays a key role in native tissue function and in its mechanical performance (14). Musculoskeletal tissues are highly anisotropic, with a composition and structure optimized to enable performance in highly loaded environments $(1,2)$. The structure of native tissues has inspired scaffold designs with aligned pore geometries to direct cell and neotissue alignment (32-36). It is possible to produce aligned scaffolds by using different methods such as ionotropic gelation $(31,37)$, 3D bioprinting (38), electro-spinning $(39,40)$ and directional freezing $(32,33,36)$. Using a directional freezing method, pore alignment can be modulated by changing the angle of the freezing surface, which in turn determines the direction of ice crystal growth (32). Such unidirectional techniques can enable the fabrication of scaffolds with an anisotropic architecture and improved mechanical properties (32, 33, 41, 42).

The overall goal of this study was therefore to develop a porous, biomimetic, shapememory alginate scaffold for directing either articular cartilage or meniscal cartilage regeneration. In order to explore how scaffold pore geometry can influence cellular recruitment and direct cellular and neo-cartilage tissue alignment, scaffolds with both isotropic (non-aligned) and anisotropic (aligned) pore geometries were produced using traditional and unidirectional freeze-drying techniques. These scaffolds were then functionalized with the addition of either type I collagen, type II collagen or chondroitin sulfate (CS). The capacity of these scaffolds to support the development of either hyaline cartilage or fibrocartilage was then assessed in vitro by seeding with human infrapatellar fat pad-derived stem cells and stimulating these constructs with transforming growth factor- $\beta 3$. Our hypothesis was that type I collagen functionalization would promote the development of meniscal cartilage (fibrocartilage), while type II collagen functionalization would promote the development of a more hyaline-like articular cartilage tissue. 


\section{Material and methods}

\subsection{Preparation of covalently crosslinked alginate scaffolds}

\subsubsection{Fabrication of alginate scaffolds with isotropic (non-aligned) pore geometries}

Alginate scaffolds with isotropic (non-aligned) pore geometries (Non-Al) were fabricated using a previously reported protocol $(23,24)$. Sodium alginate (Pronova UP LVG; Novamatrix, Sandvika, Norway) was covalently crosslinked using carbodiimide chemistry $(23,24)$. In brief, the polymer was dissolved in 2-(N-Morpholino) ethanesulfonic acid buffer (MES; pH 6.0 at 0.1 M) with $\mathrm{NaCl}(0.2 \mathrm{M})$, to a final concentration of $3.3 \%(\mathrm{w} / \mathrm{v})$. Solutions of $\mathrm{N}-\mathrm{Hydroxysuccinimide}(\mathrm{NHS})$ and 1-ethyl-3-3dimethyl aminopropyl carbodiimide (EDAC) were homogenized with alginate solution (5 minutes) with a final molar ratio of 2:1:2 for EDAC:NHS:COO- Furthermore, a crosslinking agent, adipic acid dihydrazide (AAD) (all chemicals from Sigma-Aldrich), was added to the solution (molar ratio of $45 \%$ compared to alginate $n_{\mathrm{NH}_{2}} / \mathrm{n}_{\mathrm{COOH}}$ ), quickly homogenized and transferred into a mould. The reaction was performed overnight at room temperature. Finally, the alginate hydrogel was washed several times in ultrapure water (UPW) for 24 hours to remove unreacted chemicals. After the washing step, cylinders (5 $\mathrm{mm}$ in diameter and $3 \mathrm{~mm}$ in height) of the hydrogel were cored out from the main hydrogel slab using a biopsy punch $(5 \mathrm{~mm})$. To create porous scaffolds, a freezedrying process was used $(23,24,43)$. Briefly, hydrogels were placed in a Petri dish on the cooling shelf of a laboratory freeze-dryer (Labconco Triad ${ }^{\mathrm{TM}}$, Kansas City, MO, USA) and frozen to $-30^{\circ} \mathrm{C}$ $\left(1^{\circ} \mathrm{C} \min ^{-1}\right)$ and maintained at that temperature for 1 hour. The temperature was then increased under vacuum $(0.2 \mathrm{mBar})$ to $-10{ }^{\circ} \mathrm{C}\left(1{ }^{\circ} \mathrm{C} \mathrm{min}^{-1}\right)$ and held for 24 hours, before being increased to room temperature $\left(0.5^{\circ} \mathrm{C} \mathrm{min}^{-1}\right)$.

\subsubsection{Fabrication of alginate scaffolds with anisotropic (aligned) pore geometries}

Alginate scaffolds with anisotropic aligned pore geometries (Align) were fabricated using a modified version of a previously described unidirectional freezing technique (32-34). A $20 \mathrm{~mm}$ thick stainless steel plate was cooled in liquid nitrogen, cylindrical alginate hydrogels as described above were dropped vertically onto the cold flat metal surface. Frozen blocks were transferred 
quickly with tweezers onto a pre-cooled $\left(-30^{\circ} \mathrm{C}\right)$ freeze-dryer shelf and the drying process was performed in the same manner as for Non-Al scaffolds.

\subsubsection{Functionalization of alginate scaffolds with ECM components}

The Align scaffolds were further functionalized with either type I collagen, type II collagen or CS. Type I collagen was obtained from a commercial source (extracted from rat tail, BD Biosciences, Oxford, United Kingdom). Type II collagen (collagen content of $95 \% \pm 4 \%$ ) was isolated from bovine knees and hocks using a previously reported protocol (44-46). Briefly, bovine joints were obtained locally and washed thoroughly with $70 \%$ alcohol. Cartilage slices were removed from the joints using a scalpel and minced into small pieces $(1-2 \mathrm{~mm})$. Sterile filtered $\mathrm{NaOH}(0.2 \mathrm{M})$ was added to cartilage pieces $(1 \mathrm{ml}$ per $50 \mathrm{mg})$ and rotated for 24 hours at $4^{\circ} \mathrm{C}$. The suspension was centrifuged $\left(2500 \mathrm{~g} ; 10 \mathrm{~min} ; 4^{\circ} \mathrm{C}\right)$ and the supernatant discarded (repeated 3 times). Cartilage pieces were re-suspended in activated pepsin solution $\left(1500 \mathrm{U} \mathrm{ml}^{-1}\right)$ at a ratio of $1 \mathrm{ml}$ per $50 \mathrm{mg}$ of tissue. The suspension was homogenized vigorously and incubated on a rotating platform for 24 hours $\left(20^{\circ} \mathrm{C} ; 4 \mathrm{rpm}\right)$. The solution was centrifuged $\left(2800 \mathrm{~g} ; 1 \mathrm{hr} ; 4^{\circ} \mathrm{C}\right)$ and the supernatant transferred to a tube. Sterile filtered $\mathrm{NaCl}(5 \mathrm{M})$ was slowly added into the tube in order to obtain a final concentration of $0.9 \mathrm{M} \mathrm{NaCl}$. The solution was homogenized and allowed to equilibrate overnight $\left(4^{\circ} \mathrm{C}\right)$. Thereafter, the mixture was centrifuged, the supernatant discarded and the pellet washed with UPW. Collagen was re-suspended in sterile filtered acetic acid (10 ml; $0.5 \mathrm{M})$ and allowed to solubilize overnight $\left(\mathrm{T}<20^{\circ} \mathrm{C} ; 4 \mathrm{rpm}\right)$. Acidic solubilized collagen was transferred to a previously prepared dialysis membrane (MWCO; $10 \mathrm{kDa}$ ) and dialyzed with mild rotation against $0.02 \mathrm{M} \mathrm{Na}_{2} \mathrm{HPO}_{4}(\mathrm{pH} 9.4)$ for 24 hours at $4^{\circ} \mathrm{C}$ with two exchanges. Dialyzed collagen solution was freeze-dried and stored in a freezer at $-20^{\circ} \mathrm{C}$ until use. All chemicals were obtained from Sigma-Aldrich.

Scaffolds were functionalized by either coating the scaffold with collagen, adapted from a previously reported protocols $(24,47,48)$, or blending collagen into the alginate prior to scaffold production. For coated scaffolds functionalized with type I (C1C) and type II (C2C) collagen, collagen solutions were prepared $(0.05 \% \mathrm{w} / \mathrm{v})$ in $0.5 \mathrm{M}$ acetic acid. After freeze-drying the alginate, $100 \mu \mathrm{l}$ of the collagen solution was soak-loaded into the dry porous scaffolds ( 1 hour; RT). The 
coated scaffold was then freeze-dried a second time using the same protocol. For the blended scaffolds, type I (C1B) and II (C2B) collagen was mixed with the initial alginate solution at a concentration of $0.05 \%(\mathrm{w} / \mathrm{v})$ of collagen in the total volume. Aligned scaffolds were additionally coated with chondroitin sulfate (Sigma-Aldrich) as a further control for functionalization. The subsequent freeze-drying steps were the same as that for the non-functionalized Align scaffold.

\subsection{Assessment of mechanical properties}

Scaffolds were mechanically tested as previously described using a standard materials testing machine with a $5 \mathrm{~N}$ load cell (Zwick Z005, Roell, Germany) (24, 43, 49). For day 0 and day 28, a preload of $0.01 \mathrm{~N}$ was applied to ensure direct contact between the scaffold or construct and the loading platens. Stress relaxation tests were performed, in which a ramp and hold cycle (displacement of $1 \mathrm{~mm} / \mathrm{s}$ until $10 \%$ strain) was obtained and maintained until equilibrium was reached. The compressive equilibrium modulus was determined by dividing the stress determined at equilibrium by the applied strain (10\%). To assess the shape-memory properties of the scaffolds, the same compressive test to $10 \%$ strain was applied before and after the application of fifty compressive cycles of $10 \%$ strain. All compressive tests were unconfined and with scaffolds or constructs maintained in PBS.

As a macroscopic assessment of their shape-memory properties, tweezers was used to compress the scaffolds. Images taken before and after compression were used to assess the ability of scaffolds to recover their original geometry.

\subsection{SEM imaging of scaffolds}

Alginate scaffolds were imaged using scanning electron microscopy (SEM) as previously described (24). Briefly, scaffolds were fixed in paraformaldehyde solution (4\%) overnight followed by several phosphate buffed saline (PBS) washings. Scaffolds were dehydrated through successive graded ethanol baths (10-100\%), fixed onto aluminum stubs, coated with gold and examined under a field emission SEM (Tescan Mira FEG-SEM XMU, Libušina, Czech Republic). Images were analyzed with Image $\mathrm{J}$ to quantify mean pore size. 


\subsection{Cell isolation and culture}

Ethical approval for the isolation of human infrapatellar fat pad (IFP) stromal cells was obtained from the institutional review board of the Mater Misericordiae University Hospital, Dublin, Ireland. Stromal cells were obtained from the infrapatellar fat pad of a healthy (non-osteoarthritic) patient undergoing anterior cruciate ligament surgery. The IFP was harvested and washed in PBS (Sigma-Aldrich), diced followed by rotation at $37^{\circ} \mathrm{C}$ in high-glucose Dulbecco's Modified Eagle Medium (hgDMEM, GlutaMAX ${ }^{\mathrm{TM}}$; Gibco, Biosciences, Ireland) containing collagenase type II (750 $\mathrm{U} \mathrm{ml^{-1 }}$, Worthington Biochemical, LaganBach Services, Ireland) and 1\% penicillin $\left(100 \mathrm{U} \mathrm{ml}^{-1}\right)$ streptomycin $\left(100 \mathrm{mg} \mathrm{ml}^{-1}\right)$ for approximately 4 hours. A ratio of $4 \mathrm{ml}$ of collagenase $\left(750 \mathrm{U} \mathrm{ml}^{-1}\right)$ per gram of IFP tissue was found to be optimal based on previous work $(49,51)$. Following tissue digestion, cells were washed, sieved with a $40 \mu \mathrm{m}$ nylon cell strainer, centrifuged (650 g; $5 \mathrm{~min}$ ), counted and finally plated $\left(5 \times 10^{3}\right.$ cells $\left.\mathrm{cm}^{-2}\right)$ in T-175 flasks (Sarstedt, Wexford, Ireland). Cells were cultured in a standard media formulation, which consisted of hgDMEM containing $10 \%$ fetal bovine serum and $1 \%$ penicillin $\left(100 \mathrm{U} \mathrm{ml}^{-1}\right)$-streptomycin $\left(100 \mathrm{mg} \mathrm{ml}^{-1}\right)$ (GIBCO, Biosciences, Ireland) with the addition of fibroblast-growth factor-2 (FGF-2, $5 \mathrm{ng} \mathrm{ml}{ }^{-1}$; ProSpec-Tany TechnoGene Ltd, Israel). Stem cells were expanded to passage 2 , at a seeding density of $5 \times 10^{3}$ cells $\mathrm{cm}^{-2}$ at each passage and media changes performed twice weekly.

For in vitro studies, $5 \times 10^{5}$ culture expanded human IFP-derived stem cells (FPSCs) were seeded onto alginate scaffolds. Before seeding, scaffolds were sterilized in $70 \%$ ethanol (30 minutes) followed by washes in sterile PBS (52). Next, the alginate/cell constructs were maintained in chemically defined chondrogenic medium (CDM), as previously described $(43,51,53)$, for 28 days $\left(5 \% \mathrm{O}_{2} ; 37^{\circ} \mathrm{C}\right)$. CDM consisted of DMEM GlutaMAX ${ }^{\mathrm{TM}}$ supplemented with penicillin (100 $\mathrm{U}$ $\left.\mathrm{ml}^{-1}\right)$-streptomycin $\left(100 \mu \mathrm{g} \mathrm{ml}^{-1}\right)$ (both Gibco, Biosciences, Ireland), sodium pyruvate $\left(100 \mu \mathrm{g} \mathrm{ml}^{-1}\right)$, L-proline $\left(40 \mu \mathrm{g} \mathrm{ml}^{-1}\right)$, L-ascorbic acid-2-phosphate $\left(50 \mu \mathrm{g} \mathrm{ml}^{-1}\right)$, bovine serum albumin (BSA) (1.5 $\mathrm{mg} \mathrm{ml}^{-1}$ ), insulin-transferrin-selenium (1x), dexamethasone (100 nM) (all from Sigma-Aldrich, Ireland) and recombinant human transforming growth factor- $\beta 3$ (TGF- $\beta 3,10 \mathrm{ng} \mathrm{ml}^{-1}$; ProSpecTany TechnoGene Ltd, Israel). Constructs were contained within cylindrical agarose moulds 
cultured in 12 well plates. Cells were allowed to attach for two hours, followed by supplementation with $2.5 \mathrm{ml}$ of CDM. Complete media changes were performed twice weekly.

\subsection{Biochemical analysis}

Alginate constructs were biochemically analyzed at day 28, for DNA, sulphated glycosaminoglycans (sGAG) and collagen content, as previously described (23, 24, 43). Briefly, constructs were enzymatically digested with papain $\left(125 \mu \mathrm{g} \mathrm{ml}^{-1}\right)$ in sodium acetate $(0.1 \mathrm{M})$, cysteine- $\mathrm{HCl}(5 \mathrm{mM})$, Ethylenediaminetetra-acetic acid (EDTA) (0.05 M), pH 6.0 (all from SigmaAldrich) at $60^{\circ} \mathrm{C}$ under rotation (10 rpm; 18 hours). DNA content of each sample was quantified using the Hoechst Bisbenzimide 33258 dye assay, with a calf thymus DNA standard as previously described $(23,24)$. Proteoglycan content was estimated by quantifying the sGAG in constructs using the dimethylmethylene blue dye-binding assay (Blyscan, Biocolor Ltd., Northern Ireland), using a bovine chondroitin sulfate standard (23). Collagen content was quantified by measuring hydroxyproline content, after acidic hydrolysis of the samples $\left(110^{\circ} \mathrm{C} ; 18\right.$ hours $)$ in concentrated HCL $(38 \%)(23,24,43)$. Samples were assayed using a chloramine-T assay assuming a hydroxyproline/collagen ratio of 1:7.69 (50).

\subsection{Histology and immunohistochemistry}

Alginate constructs were fixed overnight $\left(4^{\circ} \mathrm{C}\right)$ in paraformaldehyde $(4 \%)$, followed by washing in PBS, dehydrated and wax embedded. Wax embedded constructs were sectioned to produce $6 \mu \mathrm{m}$ thick slices and mounted on microscope slides. Day 0 acellular Non-Al and Aligned sections were stained with $1 \%$ alcian blue $8 \mathrm{GX}$ (Sigma-Aldrich) in $\mathrm{HCl}(0.1 \mathrm{M})$ for sGAG to examine scaffold structure and material distribution. With the aim of monitoring cell colonization and the newly formed matrix, constructs were histologically analyzed through staining with aldehyde fuchsin (AF)-alcian blue, and haematoxylin and eosin (H\&E) at day 0 and 28, using previously mentioned protocols for alginate scaffolds $(23,51)$. Immunohistochemical analysis was performed on $6 \mu \mathrm{m}$ sections using monoclonal antibody to type II collagen (Abcam, UK) as previously described $(23,24,52,54)$. Briefly, samples were washed in PBS and subjected to peroxidase activity (20 minutes), incubated with chondroitinase $\mathrm{ABC}$ (Sigma, $0.25 \mathrm{U} \mathrm{ml}^{-1}$ ) for 1 
hour $\left(37^{\circ} \mathrm{C}\right.$ in a moist environment) to enhance ECM permeability, rinsed with PBS, blocked with 10\% goat serum (30 minutes) and incubated with mouse monoclonal anti-collagen type II diluted 1:100 ( $1 \mathrm{mg} \mathrm{ml}^{-1} ; 1$ hour at RT; Abcam, UK). A secondary antibody for type II collagen was then applied (1 mg ml${ }^{-1}$; 1 hour; Anti-Mouse $\operatorname{lgG}$ Biotin antibody produced in goat) followed by incubation with $\mathrm{ABC}$ reagent (Vectastain PK-400, Vector Labs, UK) for 45 min. Color was developed using the Vectastain $A B C$ reagent followed by exposure to peroxidase $D A B$ substrate kit. Samples were dehydrated with graded ethanol and xylene and mounted with Vectamount medium (Vector Laboratories, UK). Protocols were based in previously described work (23, 24, 43, 54). Sections were imaged with an Olympus IX51 inverted microscope fitted with an Olympus DP70 camera.

\subsection{Cell Viability and Actin/DAPI staining}

Cell survival and distribution were assessed using a LIVE/DEAD kit (Invitrogen, Bioscience, Ireland) as previously described $(24,43)$. Briefly, constructs were washed in PBS, sectioned in half, incubated in calcein $\left(2 \times 10^{-6} \mathrm{M}\right.$; live/green). Segments were washed and imaged using confocal microscopy 10x Olympus FV-1000 Point-Scanning Microscope (Southend-on-Sea, UK) at 515 and $615 \mathrm{~nm}$ channels and analyzed using FV10-ASW 2.0 Viewer.

For actin staining, scaffold cross-sectional slices were incubated with fluorescent agent rhodamine-conjugated phalloidin (dilution 1:40, Biotium, Hayward, USA) combined with Hoechst (4',6-diamidino-2-phenylindole (DAPI), dilution 1:50, VWR, Ireland) in order to identify cell morphology and observe in red F-actin filaments of the cytoskeleton, and in blue the nucleus of the cell (24).

\subsection{Statistical Analysis}

Results are presented as mean \pm standard deviation. Statistical analysis was performed using MINITAB 15.1 software package (Minitab Ltd., Coventry, UK). Experimental groups were analyzed for significant differences using a general linear model (GLM) for analysis of variance (ANOVA) with factors including scaffold architecture, collagen type and functionalization method 
(i.e. coated or blended). Tukey's test for multiple comparisons was used to compare conditions. Significance was accepted at a level of $p<0.05$.

\section{Results}

\subsection{Development of a shape-memory alginate scaffold with aligned pores}

Shape-memory alginate scaffolds with both a non-aligned (Non-Al) and an aligned (Align) pore structure were produced by freeze-drying covalently crosslinked alginate hydrogels. Scanning electron microscopy (SEM) was used to characterize the morphology and size distribution of the channels/pores in both scaffold types (Figure 1). There was no obvious preferred pore alignment in the Non-Al scaffolds (Figure $1 \mathrm{~A}-\mathrm{C}$ ). Conversely, an aligned honeycomb-like pore architecture was observed in the Align scaffolds (Figure 1D-F). These differences were also observed upon histological evaluation of the scaffolds (Figure $1 \mathrm{H}$ ). The mean pore diameter for the Non-Al scaffolds was $176 \pm 70 \mu \mathrm{m}$, while the mean pore/channel diameter for the Align scaffolds was $32 \pm 12$ $\mu \mathrm{m}$. Acellular Align scaffolds were stiffer than the Non-Al group (Figure 1J).

Both covalently crosslinked scaffolds (Non-Al and Align) possessed shape-memory characteristics. When mechanically compressed, both scaffold groups recovered their original shape on unloading (Figure 2). In contrast, a collagen-based control scaffold $(43,54)$ did not maintain its original shape after compression, showing evidence of plastic deformation (Figure 2GI). No reduction was observed in mechanical properties of the shape-memory alginate scaffolds after fifty cycles of mechanical compression (data not shown).

\subsection{Scaffold pore directionality determines stem cell alignment and the extent of extracellular matrix deposition}

Both the isotropic (Non-Al) and the anisotropic (Align) scaffolds were then seeded with FPSCs and maintained for up to 28 days in chondrogenic culture conditions. Actin/DAPI staining (Figure $3 \mathrm{~A}$ ) was used to assess stem cell alignment in both scaffolds. Viable FPSCs were observed within both scaffolds at day 1 , with clustering of cells evident in both groups (Figure $3 \mathrm{~A}$ ). By day 10 it was possible to observe new matrix being produced around these clusters of cells (Figure $3 \mathrm{~A}$ ). Within the anisotropic (Align) scaffolds, the cells and the matrix they produced was 
aligned parallel to the pore structure (Figure 3A). This organization was also observed in the H\&E stained sections of the engineered tissues after 28 days in culture (Figure 3B). The composition of the tissues that formed within the scaffolds also depended on the underlying pore geometry, with higher DNA, sGAG and collagen content measured in the Align scaffolds compared to the Non-Al scaffolds after the 4 week culture period (Figure 3C). Macroscopically, scaffold anisotropy had a noticeable influence on tissue formation within FPSC seeded scaffolds, with more peripheral tissue deposition within Non-Al scaffolds (Figure 3D).

\subsection{Functionalization of shape-memory alginate scaffolds with either type I or type II collagen}

Having demonstrated that aligned scaffolds promote more robust and homogenous tissue deposition within the scaffolds, we next sought to functionalize these anisotropic scaffolds with specific ECM components to further enhance their capacity to support stem cell recruitment and chondrogenesis. Functionalization was performed by either coating the scaffold with collagen and then freeze-drying for a second time, or blending this ECM protein into the alginate prior to freezedrying. Collagen coating was confirmed histologically and using SEM (see supplementary Figure S1). We first sought to determine the impact of such ECM functionalization (type I and II collagen) on the mechanical properties of shape memory alginate scaffolds. This functionalization was only performed on Align scaffolds as they were more chondro-inductive and demonstrated superior mechanical properties (Figure 3).

Wet scaffolds were first compressed using a tweezers and again were able to return to their

original shape on unloading (Figure 4). To determine the stability of these ECM functionalized scaffolds, they were next subjected to fifty cycles of compressive strain. Only the type II collagen coated (C2C group) scaffolds demonstrated a significant decrease in mechanical properties (equilibrium modulus) after the application of cyclic loading (Figure 5). However, the stiffness of these $\mathrm{C} 2 \mathrm{C}$ scaffolds was still similar to the non-coated (NC) scaffolds after this conditioning phase. 


\subsection{Functionalizing anisotropic shape-memory scaffolds with type II collagen promotes stem cell infiltration and homogenous cartilage tissue deposition}

FPSCs were next seeded into the type I and II collagen functionalized scaffolds. Viable cells were observed in all functionalized scaffolds after ten days in culture (Figure 6). Even with ECM functionalization, FPSCs appeared to align themselves in a direction parallel to the underlying scaffold pore structure (Figure 6).

Coating with type II collagen was found to result in more homogenous tissue deposition within scaffolds seeded with FPSCs (Figure 7G-I). Similar results were observed with blended type II collagen scaffolds, although not as consistently as with coated scaffolds (Figure $7 \mathrm{~N}$ and $\mathrm{O}$ ). Pockets of newly formed tissue were observed in type I collagen coated (C1C) scaffolds (Figure 7J-L). When blended into the alginate, type I collagen typically promoted external tissue formation, with poor tissue ingrowth inside the body of the scaffold (Figure 7P-R).

Aldehyde fuchsin-alcian blue and H\&E histological staining was performed after 4 weeks in culture to assess spatial tissue deposition within the scaffolds. As noted previously, ECM was primarily deposited on the periphery of scaffolds not functionalized with collagen. Only small pockets of new tissue formation were observed inside the body of the scaffolds (Figure $8 \mathrm{I}$ and $\mathrm{L}$ ). Coating the scaffolds with type II collagen (C2C) promoted the robust deposition of new matrix inside the body of the scaffolds (Figure $8 \mathrm{O}$ and $\mathrm{R}$ ). While coating with type I collagen (C1C) also facilitated tissue deposition within the body of the scaffold, staining for sGAG deposition was generally less intense than the C2C scaffolds (Figure 8S-X). Blending of alginate with type II collagen (C2B) prior to scaffold fabrication was also found to result in more homogenous tissue deposition within the scaffold, although the intensity of staining was less than in $\mathrm{C} 2 \mathrm{C}$ scaffolds (Figure 8Y-d). Newly formed tissue was mainly deposited on the surface of the type I collagen blended (C1B) scaffolds (Figure 8e and $\mathrm{h}$; exclusively above the dashed line).

The specific types of collagen that filled the pores of the scaffolds also depended on the type of collagen they were functionalized with. The tissue that formed within $\mathrm{C} 2 \mathrm{C}$ scaffolds stained more homogenously and intensely for type II collagen than all other groups, including uncoated and $\mathrm{C} 1 \mathrm{C}$ scaffolds. Over 28 days of culture, these $\mathrm{C} 2 \mathrm{C}$ scaffolds filled with a neo-cartilage tissue 
(Supplementary Figure S2). The newly formed tissue within these C2C scaffolds stained weakly for type I collagen (Figure 9M-O). Small pockets of tissue staining positively for type II collagen were also observed in other scaffolds, including those functionalized with type I collagen (e.g. Figure 9E; $V-X ; i)$.

\subsection{Functionalizing anisotropic scaffolds with type II collagen results in the development of a more mechanically functional cartilaginous matrix}

Tissues engineered with these collagen functionalized scaffolds were also analyzed biochemically to determine their DNA, sGAG, and collagen content, and mechanically tested to determine their equilibrium stiffness (Figure 10). FPSC proliferation (as measured by DNA content) was greater in the collagen type II coated (C2C) scaffolds (Figure 10A). sGAG (Figure 10B) and collagen (Figure 10C) accumulation was greater in C2C compared to C1C scaffolds. Mechanically the C2C scaffolds were stiffer than both the control NC and C1C groups (Figure 10D).

FPSCs were also seeded for 4 weeks in scaffolds coated with chondroitin sulfate. While cells remained viable on these scaffolds, and the newly deposited tissue aligned in a direction parallel to pore architecture, overall levels of sGAG and collagen deposition were lower than in control scaffolds not functionalized with chondroitin sulfate (data not shown).

\section{Discussion}

The overall goal of this study was to develop a biomimetic, shape-memory alginate scaffold for cartilage tissue engineering applications. We sought to improve the mechanical properties of covalently crosslinked alginate scaffolds whilst simultaneously enhancing their chondroinductivity. To this end the pore architecture was modified to mimic the aligned collagen network typically observed in load bearing cartilaginous tissues (e.g. the deep zone of articular cartilage or the outer region of the meniscus), and the scaffold was additionally functionalized with either type I (the main type of collagen in meniscal cartilage) or type II collagen (the main type of collagen in hyaline/articular cartilage). Porosity was modified using a directional freezing technique (34), enabling the creation of aligned pores within the alginate scaffold. These anisotropic scaffolds were stiffer than their counterparts with more isotropic pore geometries, and furthermore these 
geometrical features were found to direct stem cell migration, alignment and facilitated more homogenous neo-tissue deposition within the scaffold. Furthermore, the additional incorporation of type II collagen onto the surface of these scaffolds facilitated the formation of a hyaline cartilagelike tissue rich in SGAG and type II collagen. The tissues that formed within these type II collagen coated scaffold were also stiffer than those generated within scaffolds coated with type I collagen. These findings open up the possibility of using anisotropic shape-memory scaffolds, functionalized with type II collagen extracted from articular cartilage, to regenerate cartilage defects.

A directional freeze-dying strategy was used to develop covalently crosslinked alginate scaffolds with anisotropic pore geometry, which improved the mechanical properties of the scaffold without compromising its shape-memory properties. It has previously been shown that introducing vertical pore alignment in chitosan-gelatin scaffolds improves their structural mechanical properties (32). A further advantage of modifying scaffold pore geometry is that it can provide structural cues to resident cells, which in turn can facilitate the engineering of complex tissues $(31-34,55,56)$. In the context of articular cartilage regeneration, such an approach can potentially be leveraged to recapitulate the structural anisotropy of the tissue (32). Indeed, introducing pore alignment was found to enhance stem cell migration, proliferation and the deposition of cartilage-specific extracellular matrix within the scaffold. Furthermore, neo-tissue alignment was determined by the underlying scaffold architecture. Previous studies (57) have demonstrated that MSCs align and produce more mature collagen fibrils along the length of channels with widths of $25-100 \mu \mathrm{m}$ (compared to channels of larger width), a comparable geometrical cue to the aligned pores (mean diameter $=32 \mu \mathrm{m})$ within our anisotropic scaffolds.

In spite of the promising features of the aligned shape-memory alginate scaffold (Align), they still suffered from a number of limitations, including poor cell attachment, limited cell proliferation and inhomogeneous neo-tissue deposition throughout the construct $(23,31)$. This is likely due to the absence of binding sites within the unmodified alginate to facilitate cell-scaffold interactions, which reduces cell seeding efficiency that leads to heterogeneous tissue formation $(23,24,31)$ mainly around the periphery of the scaffold. To overcome such a limitation it is possible to functionalize the alginate with ECM components such as fibronectin (31) and collagen 
(24). Motivated by previous studies (27) we functionalized these alginate scaffolds with either type I or type II collagen. In general, the alginate scaffolds retained their shape-memory capability following ECM functionalization, with a type II collagen coating found to increase the stiffness of the scaffold relative to uncoated controls. However this $\mathrm{C} 2 \mathrm{C}$ scaffold also demonstrated a significant reduction in mechanical properties after cyclic loading, likely due to physical damage to the collagen coating during cyclic loading. Future studies will explore chemically modifying the alginate to promote chemical crosslinking with the coated collagen in an attempt to improve the long-term mechanical performance of the scaffold (58).

Functionalizing the alginate scaffold with collagen enhanced cartilage-specific ECM accumulation, particularly when coated with type II collagen. The same was not observed with chondroitin sulfate functionalization. Several previous studies have used type I and/or II collagen as cues to enhance tissue engineering strategies $(27,28,59-61)$. While functionalization with type I collagen also enhanced neo-tissue deposition within the body of the scaffold, it did not promote comparable levels of cell proliferation and chondrogenesis as type II collagen coated scaffolds. This is in agreement with previous studies that have demonstrated the superiority of type II over type I collagen for promoting chondrogenesis $(18,21,22,28,59,60,62)$. For example, superior cell differentiation and chondrogenic gene expression was previously observed when bovine stem cells were encapsulated in a type II collagen device, when compared with type I collagen (28). Another important finding of this study was the more efficient penetration and robust proliferation of stem cells within the type II compared to the type I collagen coated scaffolds. This finding is also in agreement with a previous study were chondrocytes were seeded into collagen-sGAG scaffolds containing different types of collagen (18). They found that cells were mainly located at the periphery of type I collagen scaffolds, whilst type II collagen containing matrices supported a more homogeneous distribution of the cells throughout the scaffold (18). The favorable chondrogenesis observed in such type II collagen devices may be mediated by specific integrin binding, which is crucial to maintain the chondrogenic phenotype and chondrocyte function (27, 63-66). Type II collagen can improve chondrogenesis through integrin interactions, which modulate the transforming growth factor signaling cascade critical for chondrogenesis $(21,67)$. This collagen 
type is also known to improve cell attachment and chondrogenesis not only via integrins, but also with discoidin and annexin $\mathrm{V}$ receptors $(21,60,66,68,69)$. However there are limitations which hamper the use of type II collagen alone as scaffolding material, including poor mechanical properties. However, as we have demonstrated in this study, type II collagen can be used to functionalize other scaffolds with mechanical properties more compatible with challenging mechanical environments.

We had initially hypothesized that functionalization with type I collagen would lead to the development of a more fibrocartilage tissue, however there was no evidence of greater levels of type I collagen deposition by FPSCs within these particular scaffolds. There was also evidence for type I collagen deposition within the type II collagen functionalized scaffolds, although overall more intense staining for type II collagen was observed, further supporting our contention that these scaffolds were supporting the development of a more hyaline-like cartilage rather than a fibrocartilaginous tissue. We have previously shown that FPSCs do produce both type I and type II collagen when stimulated with TGF- $\beta 3(70,71)$, but when exposed to high levels of hydrostatic pressure mimicking that within articular cartilage, produce predominantly type II collagen (72). Future studies will explore if coating alginate scaffolds with a blend of both type I and type II collagen will be more beneficial for meniscal tissue engineering.

\section{Conclusion}

This study describes the development of an anisotropic, biomimetic, shape-memory scaffold for articular cartilage repair. It was demonstrated that functionalization with type II collagen enhances stem cell migration, proliferation and subsequent chondrogenesis. These findings support the concept that anisotropy and functionalization with tissue specific ECM coatings may overcome many of the limitations associated with current scaffolds for cartilage tissue engineering. The appropriate design of such scaffolds may support the development of spatially complex tissues such as hyaline cartilage. Furthermore, the incorporation of architectural cues into such scaffolds may also enable their use for the regeneration of fibrocartilaginous tissues such as the meniscus. The shape-memory feature of this scaffold will also enable the use of such a device in 
minimally invasive surgeries, in addition to providing physical support to cells delivered to mechanically challenging joint environments.

\section{Acknowledgments}

Funding for this study was provided by a European Research Council Starter Grant (StemRepair - Project number: 258463), Programme for Research in Third-Level Institutions (PRTLI) - Graduate Research Education Programme in Engineering, and co-funded by the European Regional Development Fund and the HEA.

\section{References}

1. Gannon AR, Nagel T, Kelly DJ. The role of the superficial region in determining the dynamic properties of articular cartilage. Osteoarthritis and cartilage / OARS, Osteoarthritis Research Society.20:1417-25. 2012.

2. Mow VC, Guo XE. Mechano-electrochemical properties of articular cartilage: their inhomogeneities and anisotropies. Annual review of biomedical engineering.4:175-209. 2002.

3. Madeira C, Santhagunam A, Salgueiro JB, Cabral JM. Advanced cell therapies for articular cartilage regeneration. Trends Biotechnol.33:35-42. 2015.

4. Felson DT. Osteoarthritis of the Knee. New England Journal of Medicine.354:841-8. 2006.

5. Steinwachs MR, Guggi T, Kreuz PC. Marrow stimulation techniques. Injury.39 Suppl 1:S26-31. 2008.

6. Hangody L, Fules P. Autologous osteochondral mosaicplasty for the treatment of full-thickness defects of weight-bearing joints: ten years of experimental and clinical experience. The Journal of bone and joint surgery American volume.85-A Suppl 2:25-32. 2003.

7. Zuk PA, Zhu M, Mizuno $\mathrm{H}$, Huang J, Futrell JW, Katz AJ, et al. Multilineage cells from human adipose tissue: implications for cell-based therapies. Tissue Eng.7:211-28. 2001.

8. Gillogly SD, Wheeler KS. Autologous Chondrocyte Implantation With Collagen Membrane. Sports medicine and arthroscopy review.23:118-24. 2015.

9. Griffin DJ, Bonnevie ED, Lachowsky DJ, Hart JC, Sparks HD, Moran N, et al. Mechanical characterization of matrix-induced autologous chondrocyte implantation ( $\mathrm{MACl}(\mathrm{R}))$ grafts in an equine model at 53 weeks. J Biomech.48:1944-9. 2015.

10. Place ES, Evans ND, Stevens MM. Complexity in biomaterials for tissue engineering. Nat Mater.8:457-70. 2009.

11. Baker BM, Gee AO, Sheth NP, Huffman GR, Sennett BJ, Schaer TP, et al. Meniscus tissue engineering on the nanoscale: from basic principles to clinical application. The journal of knee surgery.22:45-59. 2009. 
12. Malafaya PB, Silva GA, Reis RL. Natural-origin polymers as carriers and scaffolds for biomolecules and cell delivery in tissue engineering applications. Advanced Drug Delivery Reviews.59:207-33. 2007.

13. Oliveira SM, Reis RL, Mano JF. Towards the design of $3 D$ multiscale instructive tissue engineering constructs: Current approaches and trends. Biotechnology advances.33:842-55. 2015.

14. Hutmacher DW. Scaffolds in tissue engineering bone and cartilage. Biomaterials.21:2529-43. 2000.

15. Gomes ME, Malafaya PB, Reis RL. Methodologies for processing biodegradable and natural origin scaffolds for bone and cartilage tissue-engineering applications. Methods in molecular biology (Clifton, NJ).238:65-76. 2004.

16. Sutherland AJ, Converse GL, Hopkins RA, Detamore MS. The Bioactivity of Cartilage Extracellular Matrix in Articular Cartilage Regeneration. Advanced Healthcare Materials.4:2939. 2015.

17. Benders KEM, Weeren PRv, Badylak SF, Saris DBF, Dhert WJA, Malda J. Extracellular matrix scaffolds for cartilage and bone regeneration. Trends in Biotechnology.31:169-76. 2013.

18. Pieper JS, van der Kraan PM, Hafmans T, Kamp J, Buma P, van Susante JL, et al. Crosslinked type II collagen matrices: preparation, characterization, and potential for cartilage engineering. Biomaterials.23:3183-92. 2002.

19. Murphy CM, Haugh MG, O'Brien FJ. The effect of mean pore size on cell attachment, proliferation and migration in collagen-glycosaminoglycan scaffolds for bone tissue engineering. Biomaterials.31:461-6. 2010.

20. Matsiko A, Levingstone TJ, Gleeson JP, O'Brien FJ. Incorporation of TGF-beta 3 within collagen-hyaluronic acid scaffolds improves their chondrogenic potential. Adv Healthc Mater.4:1175-9. 2015.

21. Ragetly G, Griffon DJ, Chung YS. The effect of type II collagen coating of chitosan fibrous scaffolds on mesenchymal stem cell adhesion and chondrogenesis. Acta biomaterialia.6:398897. 2010.

22. Ragetly GR, Griffon DJ, Lee HB, Chung YS. Effect of collagen II coating on mesenchymal stem cell adhesion on chitosan and on reacetylated chitosan fibrous scaffolds. Journal of materials science Materials in medicine.21:2479-90. 2010.

23. Guillaume O, Daly A, Lennon K, Gansau J, Buckley SF, Buckley CT. Shape-memory porous alginate scaffolds for regeneration of the annulus fibrosus: effect of TGF-beta3 supplementation and oxygen culture conditions. Acta biomaterialia.10:1985-95. 2014.

24. Guillaume O, Naqvi SM, Lennon K, Buckley CT. Enhancing cell migration in shape-memory alginate-collagen composite scaffolds: In vitro and ex vivo assessment for intervertebral disc repair. Journal of biomaterials applications.29:1230-46. 2015. 
25. Alsberg E, Anderson KW, Albeiruti A, Rowley JA, Mooney DJ. Engineering growing tissues. Proc Natl Acad Sci U S A.99:12025-30. 2002.

26. Olderøy MØ, Lilledahl MB, Beckwith MS, Melvik JE, Reinholt F, Sikorski $P$, et al. Biochemical and structural characterization of neocartilage formed by mesenchymal stem cells in alginate hydrogels. PLoS ONE.9. 2014.

27. Rutgers $M$, Saris $D B$, Vonk LA, van Rijen MH, Akrum V, Langeveld $D$, et al. Effect of collagen type I or type II on chondrogenesis by cultured human articular chondrocytes. Tissue engineering Part A.19:59-65. 2013.

28. Bosnakovski D, Mizuno M, Kim G, Takagi S, Okumura M, Fujinaga T. Chondrogenic differentiation of bovine bone marrow mesenchymal stem cells (MSCs) in different hydrogels: influence of collagen type II extracellular matrix on MSC chondrogenesis. Biotechnol Bioeng.93:1152-63. 2006.

29. Levingstone TJ, Matsiko A, Dickson GR, O'Brien FJ, Gleeson JP. A biomimetic multi-layered collagen-based scaffold for osteochondral repair. Acta biomaterialia.10:1996-2004. 2014.

30. Wang L, Shansky J, Borselli C, Mooney D, Vandenburgh H. Design and fabrication of a biodegradable, covalently crosslinked shape-memory alginate scaffold for cell and growth factor delivery. Tissue engineering Part A.18:2000-7. 2012.

31. Yamamoto M, James D, Li H, Butler J, Rafii S, Rabbany S. Generation of stable co-cultures of vascular cells in a honeycomb alginate scaffold. Tissue engineering Part A.16:299-308. 2010.

32. Arora A, Kothari A, Katti DS. Pore orientation mediated control of mechanical behavior of scaffolds and its application in cartilage-mimetic scaffold design. Journal of the mechanical behavior of biomedical materials.51:169-83. 2015.

33. Jia S, Liu L, Pan W, Meng G, Duan C, Zhang L, et al. Oriented cartilage extracellular matrixderived scaffold for cartilage tissue engineering. Journal of Bioscience and Bioengineering.113:647-53. 2012

34. Zhang H, Hussain I, Brust M, Butler MF, Rannard SP, Cooper Al. Aligned two- and threedimensional structures by directional freezing of polymers and nanoparticles. Nat Mater.4:78793. 2005.

35. Sill TJ, von Recum HA. Electrospinning: Applications in drug delivery and tissue engineering. Biomaterials.29:1989-2006. 2008.

36. Porrelli D, Travan A, Turco G, Marsich E, Borgogna M, Paoletti S, et al. AlginateHydroxyapatite Bone Scaffolds with Isotropic or Anisotropic Pore Structure: Material Properties and Biological Behavior. Macromolecular Materials and Engineering.300:989-1000. 2015.

37. Popa EG, Caridade SG, Mano JF, Reis RL, Gomes ME. Chondrogenic potential of injectable kappa-carrageenan hydrogel with encapsulated adipose stem cells for cartilage tissueengineering applications. J Tissue Eng Regen Med.9:550-63. 2015.

38. Murphy SV, Atala A. 3D bioprinting of tissues and organs. Nat Biotech.32:773-85. 2014. 
39. Binulal NS, Natarajan A, Menon D, Bhaskaran VK, Mony U, Nair SV. PCL-gelatin composite nanofibers electrospun using diluted acetic acid-ethyl acetate solvent system for stem cellbased bone tissue engineering. Journal of biomaterials science Polymer edition.25:325-40. 2014.

40. Garrigues NW, Little D, Sanchez-Adams J, Ruch DS, Guilak F. Electrospun cartilage-derived matrix scaffolds for cartilage tissue engineering. Journal of biomedical materials research Part A.102:3998-4008. 2014.

41. Caliari SR, Ramirez MA, Harley BAC. The development of collagen-GAG scaffold-membrane composites for tendon tissue engineering. Biomaterials.32:8990-8. 2011.

42. Mandal BB, Gil ES, Panilaitis B, Kaplan DL. Laminar Silk Scaffolds for Aligned Tissue Fabrication. Macromolecular Bioscience.13:48-58. 2013.

43. Almeida HV, Cunniffe GM, Vinardell T, Buckley CT, O'Brien FJ, Kelly DJ. Coupling Freshly Isolated CD44+ Infrapatellar Fat Pad-Derived Stromal Cells with a TGF- $\beta 3$ Eluting Cartilage ECM-Derived Scaffold as a Single-Stage Strategy for Promoting Chondrogenesis. Advanced Healthcare Materials.4:1043-53. 2015.

44. Seyer JM, Brickley DM, Glimcher MJ. The isolation of two types of collagen from embryonic bovine epiphyseal cartilage. Calc Tis Res.17:25-41. 1974.

45. Herbage D, Bouillet J, Bernengo JC. Biochemical and physiochemical characterization of pepsin-solubilized type-Il collagen from bovine articular cartilage. Biochemical Journal.161:303-12. 1977.

46. Miller EJ. Structural studies on cartilage collagen employing limited cleavage and solubilization with pepsin. Biochemistry.11:4903-9. 1972.

47. Wojtowicz AM, Shekaran A, Oest ME, Dupont KM, Templeman KL, Hutmacher DW, et al. Coating of biomaterial scaffolds with the collagen-mimetic peptide GFOGER for bone defect repair. Biomaterials. 31:2574-82. 2010.

48. Mun-Hwan L, Changkook Y, Kyo-Han K. Combined Effect of a Microporous Layer and Type I Collagen Coating on a Biphasic Calcium Phosphate Scaffold for Bone Tissue Engineering. Materials. 8:1150-61. 2015.

49. Buckley CT, Vinardell T, Thorpe SD, Haugh MG, Jones E, McGonagle D, et al. Functional properties of cartilaginous tissues engineered from infrapatellar fat pad-derived mesenchymal stem cells. Journal of Biomechanics.43:920-6. 2010.

50. Ignat'eva NY, Danilov NA, Averkiev SV, Obrezkova MV, Lunin VV, Sobol EN. Determination of hydroxyproline in tissues and the evaluation of the collagen content of the tissues. Journal of Analytical Chemistry.62:51-7. 2007.

51. Sheehy EJ, Mesallati T, Vinardell T, Kelly DJ. Engineering cartilage or endochondral bone: A comparison of different naturally derived hydrogels. Acta biomaterialia.13:245-53. 2015. 
52. Buckley CT, Kelly DJ. Expansion in the presence of FGF-2 enhances the functional development of cartilaginous tissues engineered using infrapatellar fat pad derived MSCs. Journal of the mechanical behavior of biomedical materials.11:102-11. 2012.

53. Steele JAM, McCullen SD, Callanan A, Autefage $H$, Accardi MA, Dini D, et al. Combinatorial scaffold morphologies for zonal articular cartilage engineering. Acta biomaterialia.10:2065-75. 2014.

54. Almeida HV, Liu Y, Cunniffe GM, Mulhall KJ, Matsiko A, Buckley CT, et al. Controlled release of transforming growth factor- $\beta 3$ from cartilage-extra-cellular-matrix-derived scaffolds to promote chondrogenesis of human-joint-tissue-derived stem cells. Acta biomaterialia. 2014.

55. Xu CY, Inai R, Kotaki M, Ramakrishna S. Aligned biodegradable nanofibrous structure: a potential scaffold for blood vessel engineering. Biomaterials.25:877-86. 2004.

56. Engelmayr GC, Jr., Cheng M, Bettinger CJ, Borenstein JT, Langer R, Freed LE. Accordion-like honeycombs for tissue engineering of cardiac anisotropy. Nat Mater.7:1003-10. 2008.

57. Chou CL, Rivera AL, Sakai T, Caplan Al, Goldberg VM, Welter JF, et al. Micrometer scale guidance of mesenchymal stem cells to form structurally oriented cartilage extracellular matrix. Tissue engineering Part A.19:1081-90. 2013.

58. Kamimura W, Hattori R, Koyama H, Miyata T, Takato T. A calcium-cross-linked hydrogel based on alginate-modified atelocollagen functions as a scaffold material. Journal of biomaterials science Polymer edition.23:609-28. 2012.

59. Nehrer S, Breinan HA, Ramappa A, Shortkroff S, Young G, Minas T, et al. Canine chondrocytes seeded in type I and type II collagen implants investigated in vitro. J Biomed Mater Res.38:95-104. 1997.

60. Nehrer S, Breinan HA, Ramappa A, Young G, Shortkroff S, Louie LK, et al. Matrix collagen type and pore size influence behaviour of seeded canine chondrocytes. Biomaterials.18:76976. 1997.

61. Freyria AM, Ronziere MC, Cortial D, Galois L, Hartmann D, Herbage D, et al. Comparative phenotypic analysis of articular chondrocytes cultured within type I or type II collagen scaffolds. Tissue engineering Part A.15:1233-45. 2009.

62. Choi B, Kim S, Lin B, Wu BM, Lee M. Cartilaginous extracellular matrix-modified chitosan hydrogels for cartilage tissue engineering. ACS applied materials \& interfaces.6:20110-21. 2014.

63. Forsyth CB, Pulai J, Loeser RF. Fibronectin fragments and blocking antibodies to alpha2beta1 and alpha5beta1 integrins stimulate mitogen-activated protein kinase signaling and increase collagenase 3 (matrix metalloproteinase 13) production by human articular chondrocytes. Arthritis Rheum.46:2368-76. 2002. 
64. Loeser RF. Growth factor regulation of chondrocyte integrins. Differential effects of insulin-like growth factor 1 and transforming growth factor beta on alpha 1 beta 1 integrin expression and chondrocyte adhesion to type VI collagen. Arthritis Rheum.40:270-6. 1997.

65. Loeser RF. Integrins and cell signaling in chondrocytes. Biorheology.39:119-24. 2002.

66. Durr J, Goodman S, Potocnik A, von der Mark H, von der Mark K. Localization of beta 1integrins in human cartilage and their role in chondrocyte adhesion to collagen and fibronectin. Exp Cell Res.207:235-44. 1993.

67. Schneiderbauer MM, Dutton CM, Scully SP. Signaling "cross-talk" between TGF-beta1 and ECM signals in chondrocytic cells. Cellular signalling.16:1133-40. 2004.

68. Reid DL, Aydelotte MB, Mollenhauer J. Cell attachment, collagen binding, and receptor analysis on bovine articular chondrocytes. Journal of orthopaedic research : official publication of the Orthopaedic Research Society.18:364-73. 2000.

69. Gigout A, Jolicoeur M, Nelea M, Raynal N, Farndale R, Buschmann MD. Chondrocyte aggregation in suspension culture is GFOGER-GPP- and beta1 integrin-dependent. The Journal of biological chemistry.283:31522-30. 2008.

70. Luo L, Thorpe SD, Buckley CT, Kelly DJ. The effects of dynamic compression on the development of cartilage grafts engineered using bone marrow and infrapatellar fat pad derived stem cells. Biomedical Materials (Bristol).10. 2015.

71. Liu Y, Buckley CT, Almeida HV, Mulhall KJ, Kelly DJ. Infrapatellar fat pad-derived stem cells maintain their chondrogenic capacity in disease and can be used to engineer cartilaginous grafts of clinically relevant dimensions. Tissue engineering Part A.20:3050-62. 2014.

72. Carroll SF, Buckley CT, Kelly DJ. Cyclic hydrostatic pressure promotes a stable cartilage phenotype and enhances the functional development of cartilaginous grafts engineered using multipotent stromal cells isolated from bone marrow and infrapatellar fat pad. Journal of Biomechanics.47:2115-21. 2014.

\section{Figures}

Figure 1 - Scanning electron microscopy (SEM) micrographs for alginate non-aligned (Non-Al; A-C) and alginate aligned (Align; D-F) acellular scaffolds. Alcian blue only staining for Non-Al $(G)$ and Align $(H)$ before cell culture. Mean pore size (I) and equilibrium modulus $(\mathrm{J})$ comparison between Non-Al and Align acellular scaffolds $\left(\mathrm{n}=3 ;{ }^{*} p<0.05\right)$.

Figure 2 - Stereoimages of acellular scaffold alginate groups Non-AI (A, B and C), Align (D, E and F) and a extracellular matrix derived control scaffold (G, H and I), before and after mechanical compression. This assessment was performed using hydrated, acellular scaffolds. 
Figure 3 - Confocal calcein live cells and actin/DAPI staining micrographs for day 1 and day 10 of culture with FPSCs for alginate non-aligned (Non-Al) and alginate aligned (Align) (A). H\&E staining for day 21 of culture for both groups (B). DNA, sGAG and collagen content after the 4 weeks culture period for Non-Al and Align groups $\left(n=3 ;{ }^{*} p<0.05\right)$ (C). Images (worst to best tissue deposition) of non-aligned (Non-Al) and alginate aligned (Align) scaffolds after the 4 week culture period with FPSCs (D).

Figure 4 - Images of (A-C) type II coated (C2C), (D-F) type I coated (C1C), (G-I) type II blended (C2B) and $(\mathrm{J}-\mathrm{L})$ type I blended $(\mathrm{C} 1 \mathrm{~B})$ alginate scaffolds before and after mechanical compression with a tweezers. This assessment was performed using hydrated, acellular scaffolds.

Figure 5 - Equilibrium modulus for all collagen coated (C2C and C1C) and blended (C2B and C1B) acellular scaffolds, before and after the application of fifty compressive $10 \%$ strain cycles $\left(n=4 ;{ }^{*} p<0.05\right)$. This assessment was performed using hydrated, acellular scaffolds. The green line represents not coated Align (NC) scaffold equilibrium modulus after the conditioning phase.

Figure 6 - Confocal calcein/live cells and actin/DAPI micrographs for day 10 of culture with FPSCs for alginate aligned scaffolds (Align) coated with type II (C2C) and type I collagen (C1C), and blended type II (C2B) and type I (C1B) collagen.

Figure 7 - Macrographs of constructs after 4 weeks in culture with FPSCs (worst to best): alginate nonaligned (Non-Al; A-C), aligned (Align; D-F), aligned coated with type II collagen (C2C; G-I), aligned coated with type I collagen (C1C; J-L), aligned blended with type II collagen (C2B; M-O) and aligned blended with type I collagen (C1B; P-R).

Figure 8 - Micrographs of aldehyde fuchsin-alcian blue and H\&E staining of constructs after 4 weeks in culture with FPSCs: alginate non-aligned (Non-Al; A-F), aligned (Align; G-L), aligned coated with type II collagen (C2C; M-R), aligned coated with type I collagen (C1C; S-X), aligned blended with type II collagen (C2B; Y-d) and aligned blended with type I collagen (C1B; e-j). Red squares indicate location of the high magnification micrographs which are shown in the centre and right hand columns of the aldehyde fuchsinalcian blue and H\&E images.

Figure 9 - Micrographs of type I collagen and type II collagen immuno staining of constructs after 4 weeks in culture with human FPSCs: alginate non-aligned (Non-Al; A-F), aligned (Align; G-L), aligned coated with type II collagen (C2C; M-R), aligned coated with type I collagen (C1C; S-X), aligned blended with type II collagen (C2B; Y-d) and aligned blended with type I collagen (C1B; e-j). Red squares indicate location of the high magnification micrographs. 
Figure 10 - DNA (A), sGAG (B), collagen (C) and equilibrium modulus (D) for alginate aligned not coated (NC), aligned scaffold coated with type I collagen (C1C) and type II collagen (C2C), after 4 weeks in culture with human FPSCs $\left(n=4 ;{ }^{*} p<0.05\right)$. Day 0 collagen values were subtracted from presented collagen quantification.

Supplementary Figure 1 - Day 0 picro-sirius red staining of (A) non-coated and (B) collagen coated scaffolds (arrows indicate regions of dense collagen deposition inside the alginate network). SEM images demonstrate that the collagen both coats the surface of the alginate and forms fibrils across the walls of the scaffold (C and D). Images were obtained in the center of the cross-section of the scaffolds.

Supplementary Figure 2 - Day 0, 14 and 28 for the type II collagen coated scaffolds immunohistochemical type II collagen analysis.

Figures

\section{Figure 1}

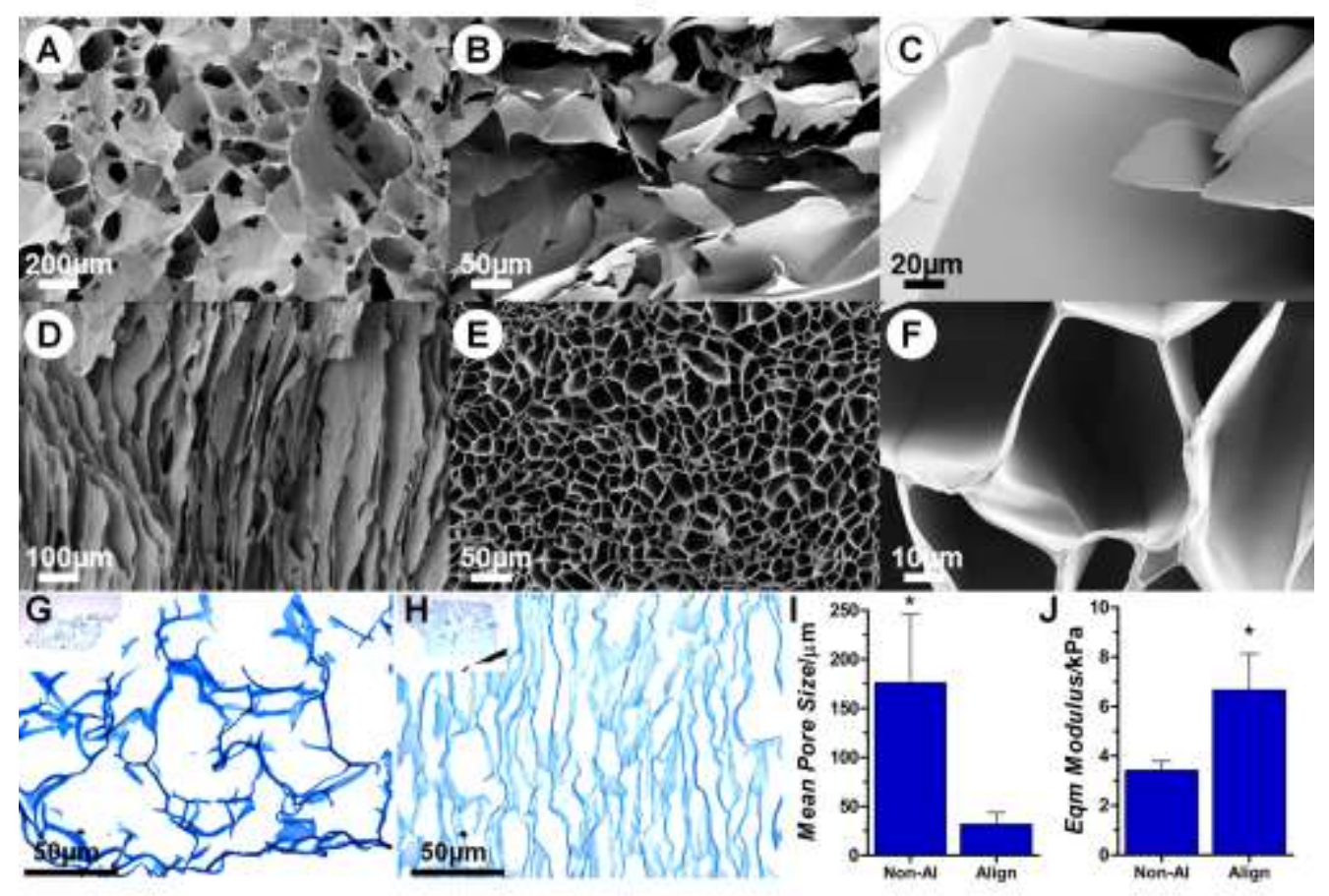


Figure 2
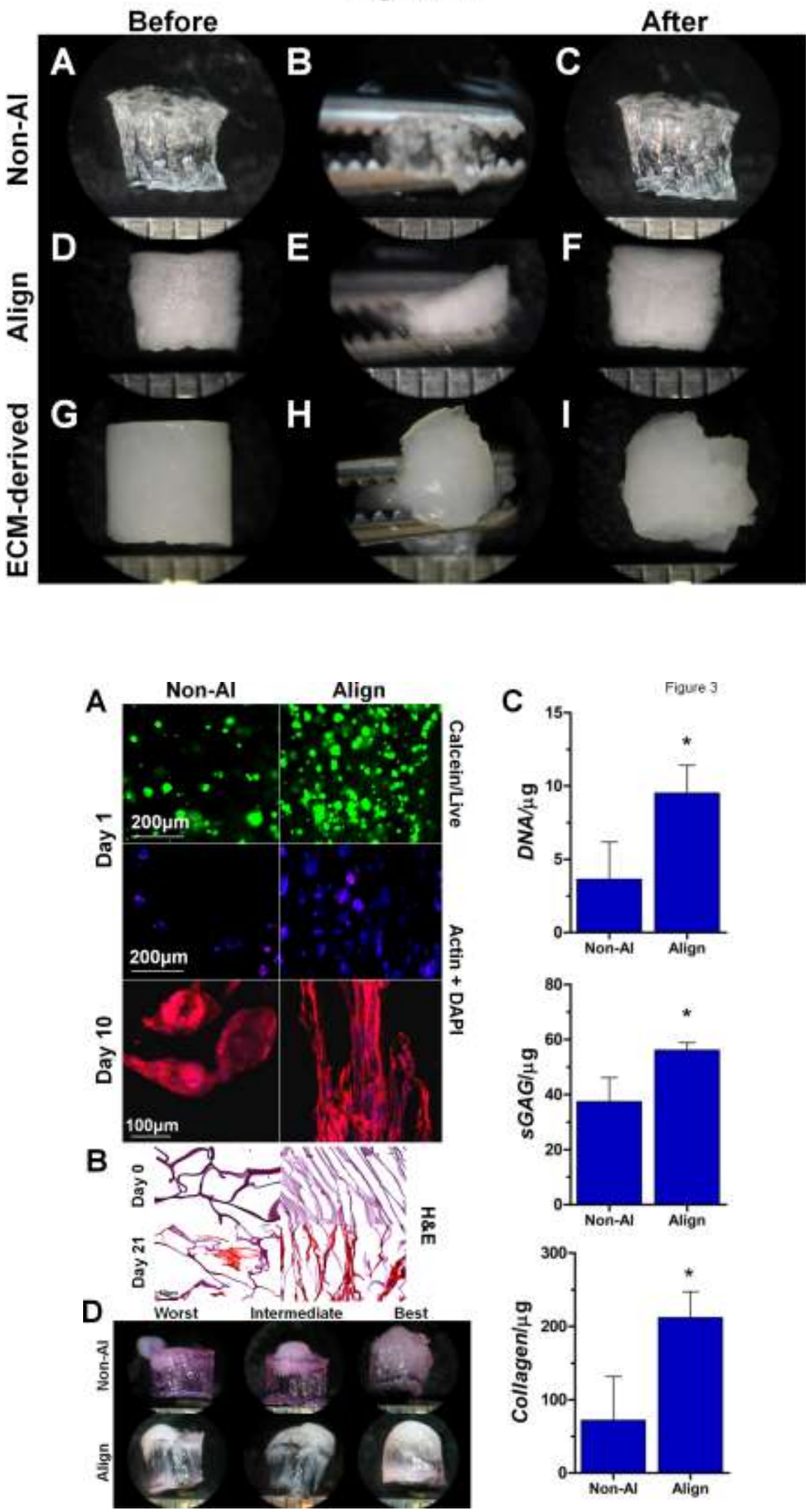
Figure 4

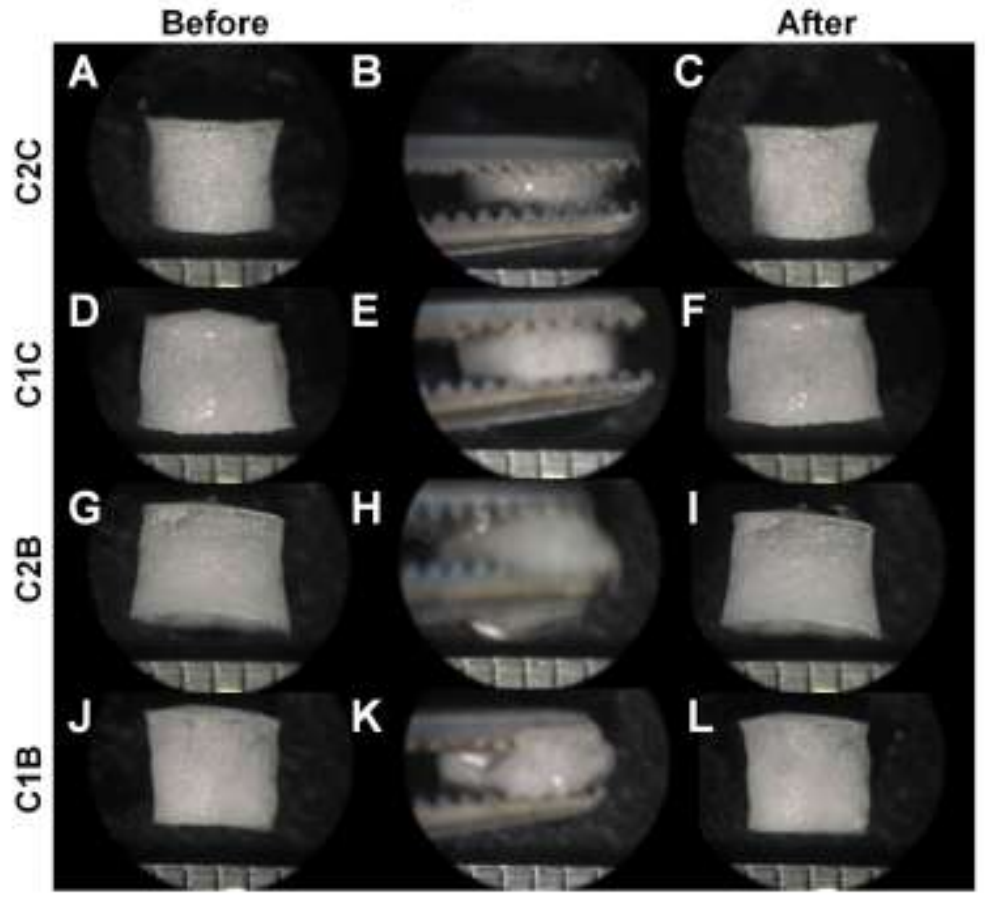

Figure 5

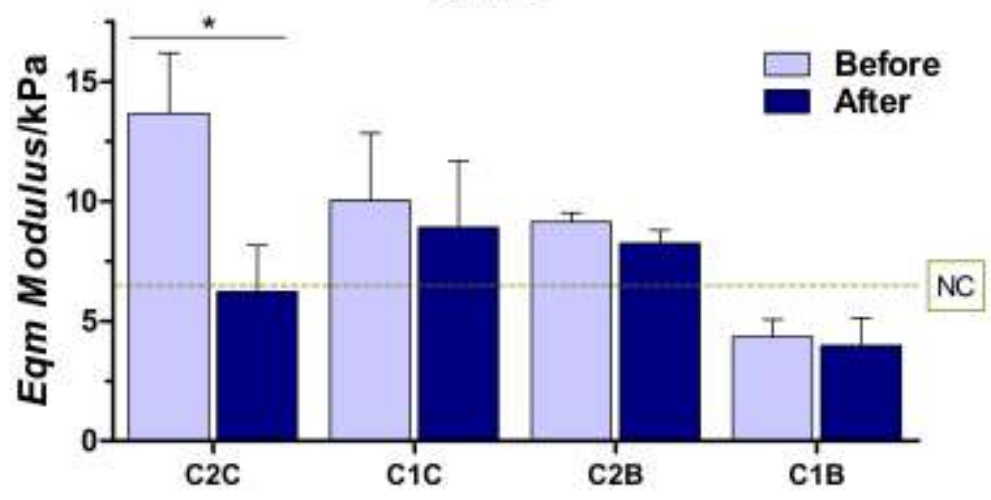


Figure 6
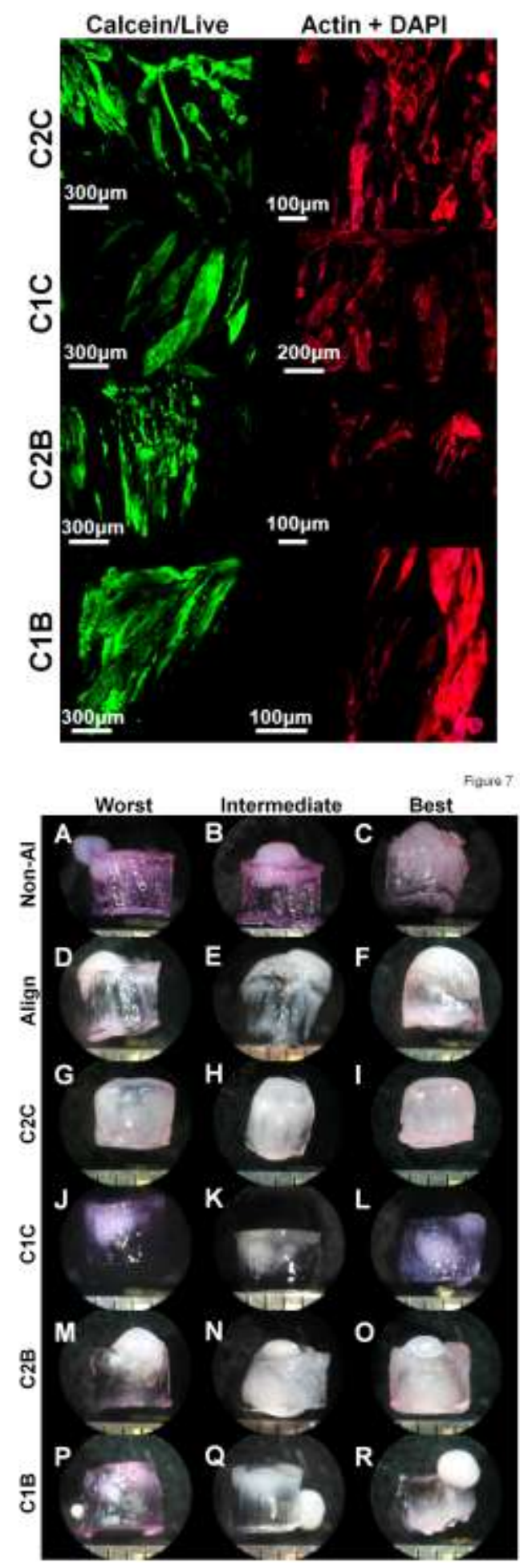

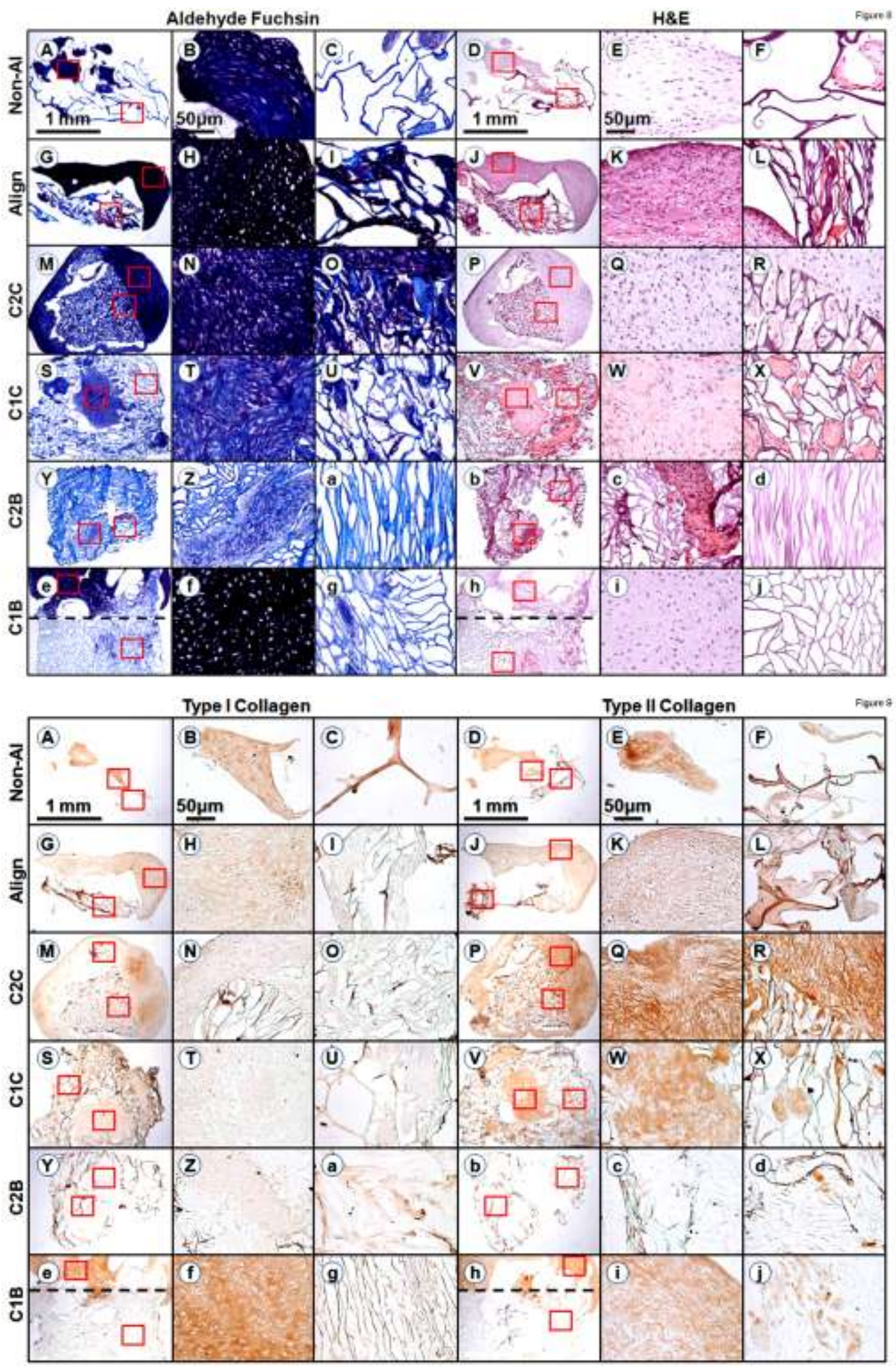

Figure 10
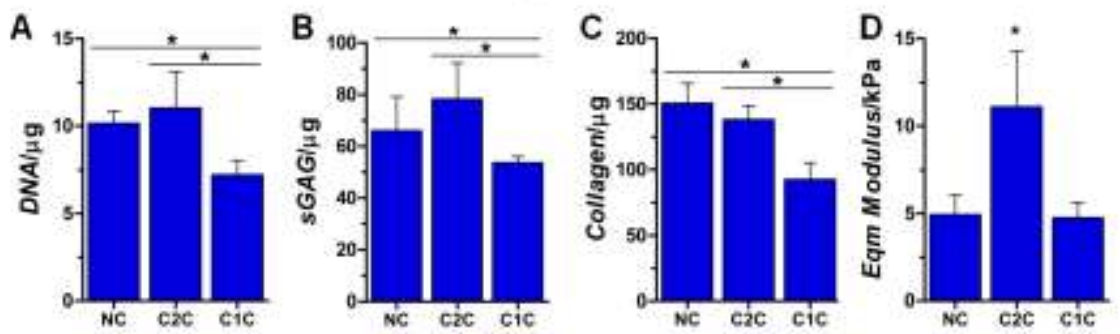
Sup 1

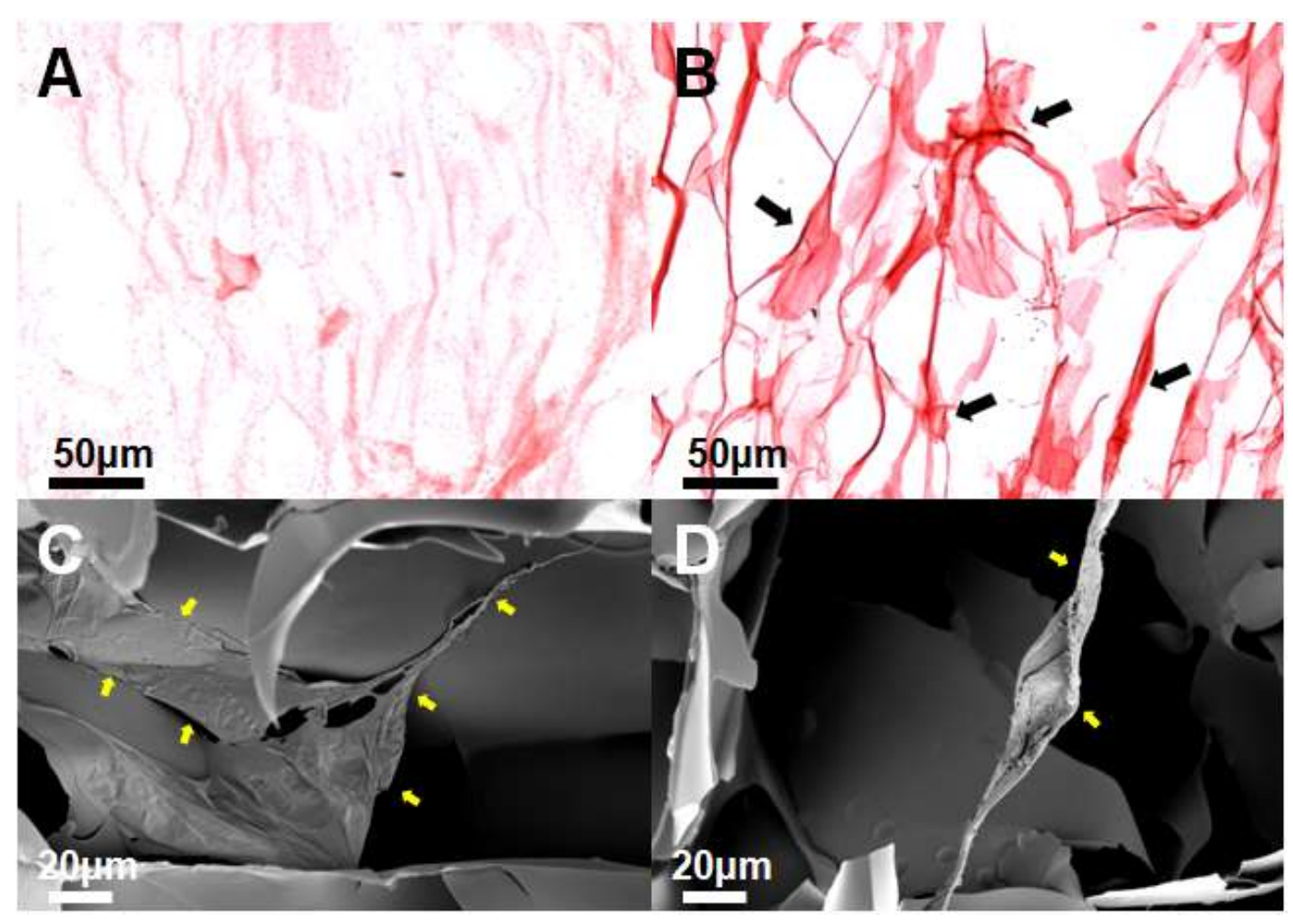

Sup 2
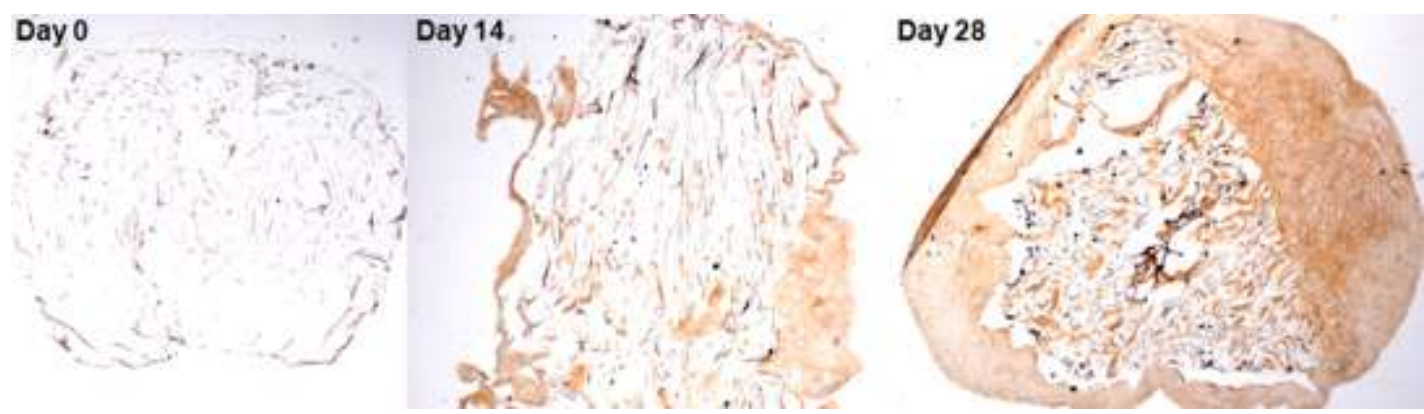